\title{
肺癌患者における塩酸イリノテカン（CPT-11）の 胸水中および心囊液中への移行性に関する検討
}

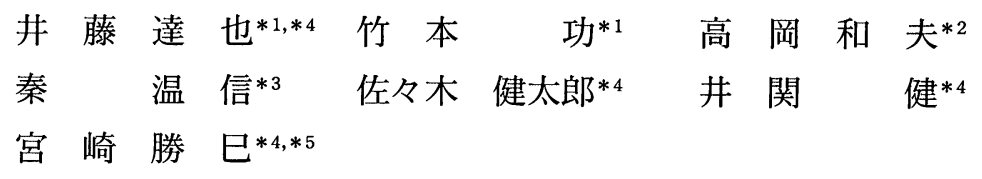

\section{【目 的】}

肺癌の胸膜への浸潤に伴う胸水貯留の治 療に化学療法が行われる. 癌性胸水中への 薬物の移行性, 特に塩酸イリノテカン （CPT-11）に関する報告は極めて少な い. 本薬物は肝で主活性代謝物 $\mathrm{SN}-38$ に変 換され抗腫瘍効果を発揮する.また, CPT-11およびSN-38は溶液のpHに依存し たラクトン環の可逆的開閉を生じ，開環

（カルボキシル）体よりも閉環（ラクト ン）体が抗腫瘍効果を示すとされている. さらに, SN-38はグルクロナイドに変換さ れることが報告されている. 今回, 肺癌患 者における本薬物の胸水中濃度, 1 症例に おいてはさらに癌が心内膜へ浸潤した心震 液中濃度の測定を行い,これら薬物の組織 移行性を検討した。

\section{【方 法】}

肺癌患者 2 名を対象にCPT-11 (60mg/ $\mathrm{m}^{2}$ ）を 90 分かけて静脈投与し患者に検体採 取の同意を得 $て$, 経時的に検体を採取し た. 症例 1 は68歳女性, 癌性胸膜炎（腺 癌）. $\mathrm{CPT}-11$ 投与後の血液と胸水を採取 した. 症例 2 は72歳男性, 癌性心膜炎（小

*1 札幌社会保険総合病院薬剂部

干 004-8618 札幌市厚別区厚別中央 2 条 6丁目 2-1

$* 2$ 札幌社会保険総合病院呼吸器内科

*3 札幌社会保険総合病院外科

*4 北海道大学大学院薬学研究科臨床薬剤学分野

*5 北海道大学医学部附属病院薬剤部
細胞癌）。CPT-11投与後に血液, 胸水求 よび心震液を採取した. 薬物の定量は巣光 モニターを用いて我々が開発したHPLC法 により行った.

\section{【結 果】}

胸水中でのCPT-11（Fig.1）, SN-38 (Fig. 2) のTmaxは各々点滴終了後7.5時 間, 24時間と血中動態よりも遅く, 肺組織 への移行性は特にSN-38で遅延しているこ とが示された. また, 血中ではSN-38の多 くがラクトン体として存在している. しか し, 胸水中ではラクトン体とカルボキシル 体を合わせた総濃度は血中と同程度まで上 昇したが, 主活性体であるラクトン体濃度 は血中の $1 / 10$ 程度と低く, 胸水中ではそ の多くがカルボキシル体となっていること が明らかとなった。一方, グルクロナイド 胸水中濃度のピークは24時間と遅いもの の, その後の消失は血中濃度推移に近似し ていた (Fig. 3).

心轀液中濃度推移はCPT-11のTmaxで 投与終了直後と血中濃度推移に類似し, 胸 水と比べCPT-11の移行性は良好であった

(Fig. 1). しかし, SN-38のTmaxは24 時間と遅く, CPT-11と比べSN-38の心裹 腔への移行性は悪かった. さらに, $\mathrm{SN}-38$ ラクトン体の割合は胸水中と同様に心輁液 中においても血中と比較し低下しているこ 


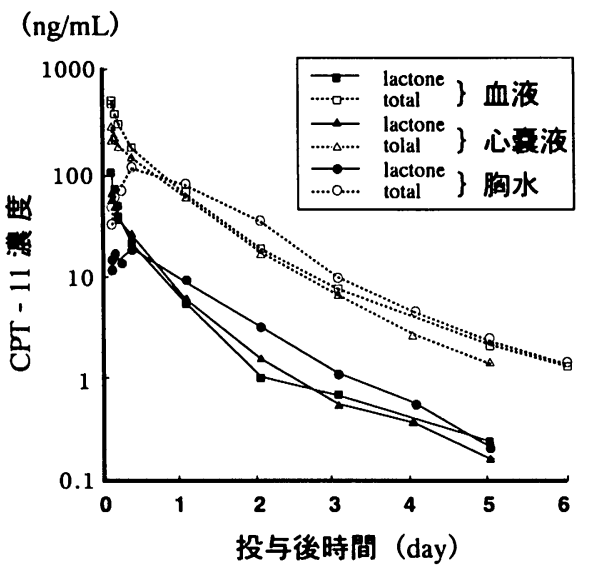

Fig.1. CPT-11 濃度推移（症例 2）

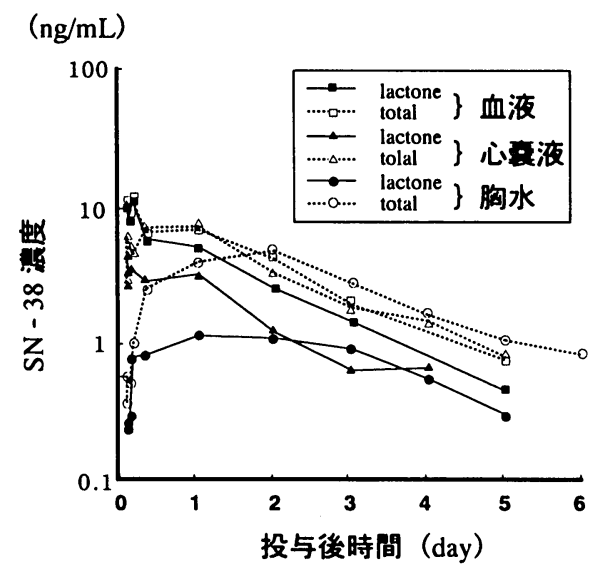

Fig.2. SN-38 濃度推移（症例 2 ）

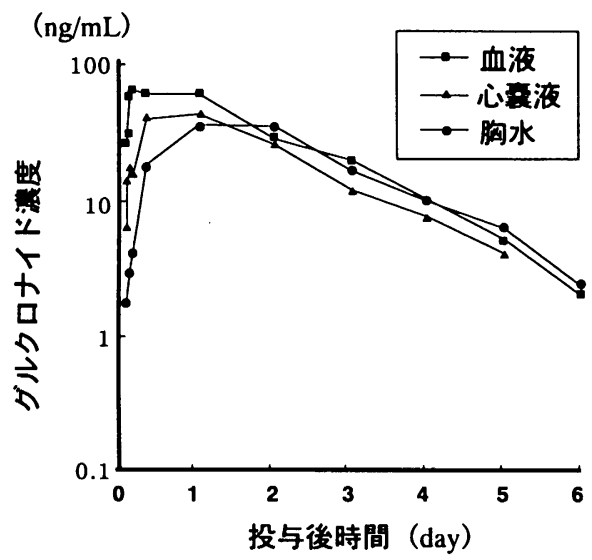

Fig.3. グルクロナイド濃度推移（症例 2）
とが明らかとなった（Fig. 2). また，グ ルクロナイド心震液中濃度推移は血中よ り若干遅れるものの, その後の消失は血 中濃度推移に近似していた（Fig. 3).

\section{【考 察】}

悪性胸膜中皮腫患者においてCPT-11お よびSN-38の胸水中への移行性に関して は良好であるとの報告 1 ) がある. 今回ラ クトン体の移行性についても検討した結 果, CPT-11では良好であったがSN-38濃 度は常に低く, ラクトン体の胸腔への移 行性は覀いことが示唆された。また，一 般に血中ではSN-38総濃度とラクトン体 濃度は極めて近い值を示すにもかかわら ず，今回の検討では胸水中でのラクトン 体濃度は低値を示した。

胸水中でのCPT-11の動態が血中より若 干遅れるものの似た挙動を示したこと は, 水溶性であるCPT-11は血行性に胸水 中へ移行したことが示唆された。しか し, 胸水中のSN-38のTmaxが血中より大 きく遅れたことは, 胸水中へ移行した CPT-11が胸腔内の細胞でSN-38へ変換さ れることにより徐々に胸水中濃度が上昇 したものと考えられる。ささらに，胸水中 のSN-38は脂溶性の高いラクトン体がリ ンパ移行性に胸腔から排泄されるために 胸水中ではカルボキシル体に比ベラクト ン体濃度が低下したものと考えられる。

また，心異液はすべて血行性に薬物は 移行するため, CPT-11, SN-38共に血中 動態に近い挙動を示したものと考えられ る.

\section{【参考文献】}

1) T. Nakano, A.P. Chahinian, M. Shinjo, et al : Cisplatin in combination Irinotecan in the Treatment of Patients with Malignant Pleural Mesothelioma., Cancer., 85 : 23752384 (1999). 